Article

\title{
Experimenting Transition to Sustainable Urban Drainage Systems-Identifying Constraints and Unintended Processes in a Tropical Highly Urbanized Watershed
}

\author{
Fernando Chapa, María Pérez and Jochen Hack *[D \\ SEE-URBAN-WATER Research Group, Section of Ecological Engineering, Institute of Applied Geosciences, \\ Technical University of Darmstadt, Schnittspahnstraße 9, 4287 Darmstadt, Germany; \\ chapa@geo.tu-darmstadt.de (F.C.); perez@geo.tu-darmstadt.de (M.P.) \\ * Correspondence: contact@geo.tu-darmstadt.de or hack@geo.tu-darmstadt.de; Tel.: +49-61511620981
}

Received: 26 November 2020; Accepted: 14 December 2020; Published: 17 December 2020

\begin{abstract}
Green Infrastructure promotes the use of natural functions and processes as potential solutions to reduce negative effects derived from anthropocentric interventions such as urbanization. In cities of Latin America, for example, the need for more nature-based infrastructure is evident due to its degree of urbanization and degradation of ecosystems, as well as the alteration of the local water cycle. In this study, an experimental approach for the implementation of a prototype is presented. The prototype consists of a gray-hybrid element for first flush bio-treatment and runoff detention, adapted to the existing stormwater sewer. The experiment took place in a highly urbanized watershed located in the Metropolitan Area of Costa Rica. The characteristics of the existing infrastructure in the study area at different scales were mapped and compared using the Urban Water System Transition Framework. Subsequently, preferences related to spatial locations and technologies were identified from different local decision-makers. Those insights were adopted to identify a potential area for the implementation of the prototype. The experiment consisted of the adaptation of the local sewer to act as a temporal reservoir to reduce the effects derived from rapid generation of stormwater runoff. Unexpected events, not considered initially in the design, are reported in this study as a means to identify the necessary adaptations of the methodology. Our study shows from an experimental learning-experience that the relation between different actors advocating for such technologies influences the implementation and operation of non-conventional technologies. Furthermore, the willingness of residents to modify their urban environments was found to be associated to their own perceptions about security and vandalism occurring in green spaces. The implementation of the prototype showed that both the hydraulic performance is relevant for considering it as a success, as well as the dynamics of the adapted element with the existing urban conditions. In consequence, those aspects should be carefully considered as the design factors of engineering elements when they are related to complex socio-ecological urban systems.
\end{abstract}

Keywords: urban drainage systems; sustainable stormwater management; Costa Rica; place-based research; transition stages

\section{Introduction}

The rapid expansion of cities and the lack of planning and management strategies throughout the past challenges the sustainability of urban water systems around the world. Despite its benefits such as sanitation or protection against flooding, the disruption of the hydrological cycle is commonly referred to as a negative impact of gray stormwater infrastructure [1,2]. Land-use change, removal of vegetation 
and topsoil, and increase of impervious surfaces reduce important hydrological functions of the landscape (e.g., interception, evapotranspiration, infiltration, or retention capacity) [3], increasing runoff volumes and peak flows [4]. Moreover, pollutants carried by stormwater runoff constitute a source of degradation to stream ecosystems [5]. The alteration of natural hydrological functions in urban areas results in a disconnection of socio-ecological dynamics [6]. The complex and dynamic interaction of man-made and environmental features influence ecological functions by altering the flow regime, for example [7]. In consequence, urban residents must adapt their habitats to those new dynamics derived from urbanization.

Urban drainage systems have been adapted to solve socio-hydrological demands, such flooding protection [8]. The societal perspective to those systems evolved depending on specific cultural and historical contexts. The perspective on stormwater has changed over time as a vital resource, efficient transport medium, flooding concern, wastewater nuisance, or transmitter of diseases [9]. Sustainable Urban Drainage Systems (SUDS) has emerged in the last few decades as an approach that aims to reduce the impacts of urbanization on local hydrology by integrating functions and processes observed in nature [10]. Similarly, the term Nature-Based Solutions appears in the science-policy-practice interface linked often to Sustainability Science [11] and the Green Infrastructure concept [12]. Terms associated to the sustainability of urban drainage systems have different denominations (e.g., Water Sensitive Urban Design, Low Impact Development, Best Management Practices, or the Sponge City concept), and may include a variety of aspects beyond stormwater runoff management [13-15]. SUDS technologies represents an opportunity for transition shifts in urban socio-ecological systems [16]. Apart from runoff control, SUDS have evolved to consider multi-functional aspects [17], including groundwater recharge, protection of water quality, enhancement of recreational and amenity facilities, aesthetics, provision of habitat for wildlife, restoration of socio-ecological connectivity, or meeting local community needs $[3,18]$. Advocates and researchers of SUDS commonly valuate the multifunctional benefits derived from their implementation using the Ecosystem Service Framework [11,19,20]. However, transitions from conventional to sustainable systems might be impeded by institutional barriers and predefined preferences [21]. In cities where a concept has been already developed, socio-institutional barriers are reported as a key limitation for their adoption [22], in which the adoption of Green Infrastructure (GI) approaches occurs at a slow pace [23]. Implementing more sustainable, nature-based infrastructure is still a challenge, and depends on site-specific characteristics.

When drainage systems are sought to contribute to the sustainability of cities, people's participation is necessary [24]. Different studies have highlighted the relevance of taking into account people's preferences in the implementation of SUDS technologies in urban areas [25-28]. Perceptions, preferences, and attitudes are influenced by the environmental experience of stakeholders $[29,30]$, and might lead to subjective assessments of specific technologies [31]. Those aspects are commonly omitted during the implementation of SUDS in cities with an advanced level of infrastructure development [32].

Since sustainability advocates for people's participation, understanding their role and adapting SUDS to local needs becomes part of the implementation challenges. Especially when urban drainage systems shall comply with multiple functions that go beyond drainage, the involvement of different actors in their planning and design becomes important. Since the novel approaches are attempted to be adopted by a wide range of actors, it is necessary to understand the factors that might limit SUDS implementation from different perspectives.

In this study, we explore the social-ecological dynamics associated with urban drainage systems, existing in a highly urbanized watershed in Costa Rica and simulate a transitional evolution of the urban drainage infrastructure at a micro-scale. The study is divided into two phases. Initially, the existing dynamics are approached by considering the perspective of different stakeholders. The understanding of such dynamics is summarized following a conceptual framework related to the evolution of urban drainage systems. Simultaneously, a neighborhood that presents socio-ecological conflicts in the watershed is identified. Local decision-makers collaborated to identify the site. In the second phase, 
a prototype is implemented in this site assuming a linear evolution of the local urban drainage system. The procedure is adopted as a strategic methodology to identify institutional constraints and unintended processes emerging during practice. Therefore, the main goal of this study is to describe such aspects experienced during both phases of the research as an empirical lesson, guiding scholars in areas with similar conditions.

\section{Materials and Methods}

The study was carried out in a highly urbanized tropical watershed. These conditions seem different from those where SUDS have been previously considered, being predominantly in sub-tropical and temperate zones where precipitation intensities as well as precipitation volumes are usually higher and dry periods are more pronounced. The existing drainage system and the socio-ecological dynamics are examined in the first phase of the research. Our approach attempts to understand spatial attributes and socio-ecological drivers, as well as perceptions and attitudes from local stakeholders. Key actors at different spatial and socio-institutional levels explained relevant conflicts related to urban water management and proposed specific sites for the experimentation of adapted solutions through the implementation of a SUDS prototype. Following a multi-level phase process of data collection and analysis, site observation, informal interviews, and hydrological monitoring were also included in the methodology. As result, the existing stage of the drainage system in the watershed was conceptualized following a transition model framework proposed by [8]. From the list of proposed sites for experimentation, we identified and selected a neighborhood that represents key water-related aspects. In the second phase, the neighborhood was intensively mapped to guide the implementation of a non-conventional SUDS prototype. The prototype design was adapted to the existing state of development, assuming a linear continuum on the evolution of the urban drainage system and following a collaborative approach with local authorities.

\subsection{First Phase: Identification of the Transitionary Stage of the Urban Water System}

\subsubsection{Study Area}

The Quebrada Seca watershed was adopted as a case study due to water-related problems (e.g., flooding, water pollution, bank erosion) reported in the past [33-36]. The watershed is located in the north-western part of the Great Metropolitan Area of Costa Rica. The $23 \mathrm{~km}^{2}$ watershed area is administratively distributed in six municipalities as shown in Figure 1. In 2011, the population density was on average 4160 inhabitants $/ \mathrm{km}^{2}$ [35]. The local hydrology is characterized by annual precipitation rates of $2042 \mathrm{~mm}$ with a temperature of $25^{\circ} \mathrm{C}$, on average, and an altitudinal gradient between 869 and 1626 m.a.s.1. [37]. The precipitation is marked by a seasonal distribution in which the rain season lasts from May to November and is influenced by the Intertropical Convergence Zone [33]. The river network is composed of two main streams and a small tributary, joining in the middle section of the watershed. The riparian zone has a protection corridor of $10 \mathrm{~m}$-wide by law however, several houses and streets shape the riparian landscape in some up- and downstream areas.

Previous studies have approached the problem derived from urbanization from different perspectives. The socio-political dynamics that rule the urban development in the watershed were associated to the historical evolution of the land cover from coffee plantations to large industrial, commercial, and residential zones [34]. From a hydrological perspective, reported flooding issues occurring periodically were attributed to a specific type of distributed rainfall events in the upstream areas [33]. Regarding urbanization, this process occurred from 1960, but with a significant increase in the last few decades with more than $51 \%$ of the total area found impermeabilized in 2010 [38]. About 97\% of the total buildings correspond to urban residences, thereby $87 \%$ correspond to single-family houses [35]. 


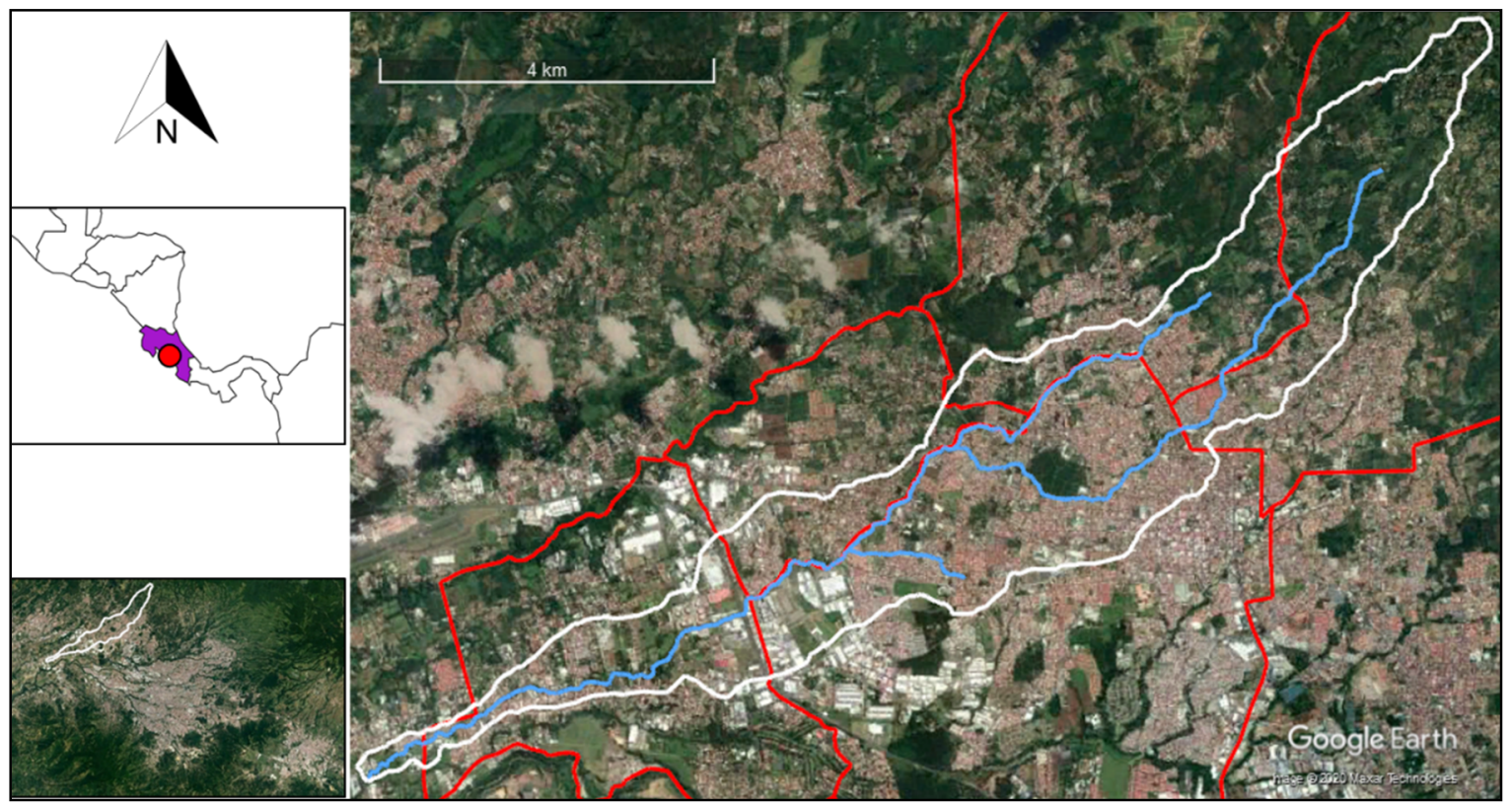

Figure 1. Overview of the Great Metropolitan Area (bottom-left) in Costa Rica and location of the Quebrada Seca-Río Burío Watershed including municipality boundaries (red lines), river network (blue line) within the watershed divide (white line).

\subsubsection{Conceptual Approach}

The Urban Water Transition Framework [8], summarized in Table 1, was employed to examine the stage of existing water infrastructure in the study area. It is based on a typology of six city stages, each one describing specific hydro-social characteristics and delivery functions. Each stage influences subsequent transition levels following a linear nested continuum. While the first four stages correspond to historical transitions observed in Australian cities, the last two stages have not been yet reported at a city-wide level, but only developed at the conceptual level. Hereinafter, each category is referred to as Stage I-VI.

\subsubsection{Identification of the Existing Transitionary Stage and Selection of a Neighborhood for Experimentation}

A three-level spatial scale approach was employed to understand the existing situation of water-related management in the watershed. The first scale, the watershed, was defined by the hydrological divide of the study area. The second spatial scale was limited by each of the five municipalities partially located within its hydrological boundaries. A sixth municipality at the downstream end of the watershed area was omitted because of its relatively small size compared with the others, and the non-existence of urban development there except for one building. Finally, the third scale was defined at the neighborhood level. These spatial scales were selected to represent different institutional constellations. Figure 2 shows a summary of the procedure employed during the first phase. In the figure, the institutions and actors considered at the watershed, municipalities, and neighborhood-scale are presented as the research evolved temporally. As the main outcome of this phase, the transitional stage was conceptualized for the watershed and a neighborhood was selected for experimentation based on proposals received from municipality representatives. 
Table 1. Urban Water Transitions Framework (adapted from [8]).

\begin{tabular}{|c|c|}
\hline Transitionary Stage & Hydro-Social Characteristics \\
\hline I Water supply city & $\begin{array}{c}\text { Centralized water supply systems: Access to safe, low cost, limitless water } \\
\text { supply as public right delivered by government. Taxing system to pay for } \\
\text { infrastructure and delivery. }\end{array}$ \\
\hline II Sewered city & $\begin{array}{l}\text { Reticulated sewerage, onsite septic systems: Public health protection through } \\
\text { the deliverance of undesired effluents to receiving waterways. Expansion of } \\
\text { water boards for sewerage services, property taxes. }\end{array}$ \\
\hline III Drained city & $\begin{array}{l}\text { Underground drainage, river channelization. Houses facing away from } \\
\text { waterways. Flood protection by rapid and cost-efficient conveyance of } \\
\text { stormwater, land reclamation of floodplain areas. Waterways are perceived as } \\
\text { waste dumping grounds. Services are delivered by centralized water supply } \\
\text { and sewerage authorities. Progressive involvement of local authorities. }\end{array}$ \\
\hline IV Waterways city & $\begin{array}{l}\text { Water as a visual and recreational feature. New technologies } \\
\text { (e.g., bio infiltration). Septic tanks are replaced by centralized sewage treatment. } \\
\text { Community demand for greater levels of amenity and access to green spaces. } \\
\text { Measures to reduce pollutant inputs into receiving waters. } \\
\text { Environmental discharge regulations. Tensions between traditional } \\
\text { (i.e., service delivery function) and environmental protection practitioners. }\end{array}$ \\
\hline V Water Cycle City & $\begin{array}{l}\text { Fit-for-purpose diverse water supplies. Conservation and protection of } \\
\text { waterway health. Recognition of limits of water supply sources and the } \\
\text { assimilation capacity of receiving waterways. Co-managed and risk-shared. } \\
\text { Remains largely at the level of academic and policy rhetoric. }\end{array}$ \\
\hline VI Water Sensitive City & $\begin{array}{l}\text { Adaptive multifunctional infrastructure. Contemporary futurist concept: } \\
\text { ecological integrity, intergenerational equity, and resilience to climate change. } \\
\text { Flexible institutional regime. Sophisticated and engaged community } \\
\text { supportive of a sustainable lifestyle. }\end{array}$ \\
\hline
\end{tabular}

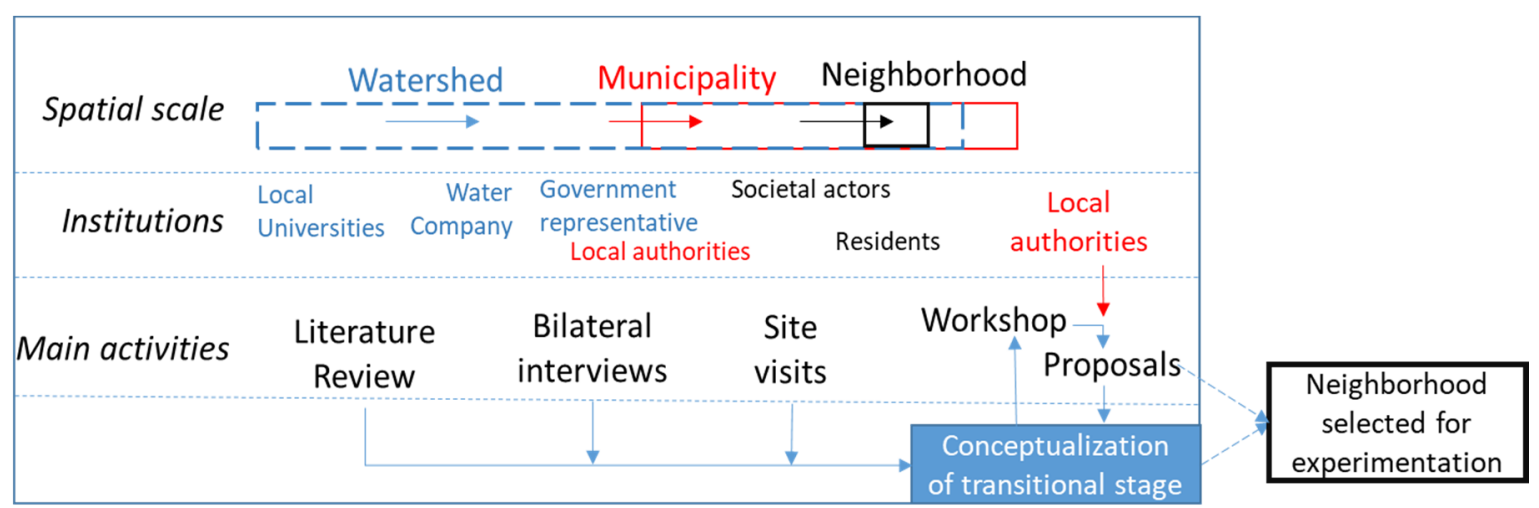

Figure 2. The methodology employed to conceptualize the existing urban water stage in the case of study considering actors at the watershed (blue), municipal (red), and neighborhood scale (black).

Since online access to previous studies was limited, academic experts provided initial and general insights concerning the constellation of actors and existing water dynamics. The experts were professionals related to water resources management, working in two universities of the country, who had previous experience researching the study area. Libraries belonging to those universities provided academic works on the topic.

The academic experts referred the authors to professionals working at the watershed or municipal level who were familiar with the topic. Following a snowball sampling method and semi-structured bilateral interviews, the institution responsible for water supply and sanitation, the representatives of the health ministry, as well as representatives of each municipality were contacted. First, the relevant water aspects occurring in the watershed were asked. Then, they referred to specific sites perceived 
as conflictive, in terms of both existing water processes and urban development. The municipal employees were persons in charge of environmental or planning aspects.

An excursion led by a local academic expert was done along the river, including the sites suggested previously by local professionals. Two of the five municipalities also accepted to guide the authors on separate excursions to the sites they considered relevant within their administrative boundaries, the two excursions took place on different days and were accompanied by a representative of the corresponding municipality. In the following days, independent excursions (i.e., without the guidance of any stakeholder) were carried out along the river to complement the information provided previously. Informal conversations occurred with residents met at public spaces. They were approached by explaining the goal of the study and the interest of the authors to understand the local water issues. Excursions and interviews took place during the first semester of 2019.

Water-related aspects identified and mapped during those activities were presented to the local authorities during a workshop. Thirteen representatives attended the event, including one mayor, two academic experts, and at least two representatives of four municipalities. The workshop was led by an expert on urban hydrology who explained the concept of Green Infrastructure and Nature-Based Solutions. The workshop began by summarizing local water-related issues (i.e., initial conceptualization of the water stage in the watershed). Participants discussed the results and presented their perspectives and possible solutions. The interest of the researchers to select a site for collaborative experimentation of non-conventional SUDS technologies was expressed. A form to propose experimental sites was introduced and exemplarily explained to the workshop participants.

Based on the provided form participants proposed possible sites for experimental intervention. The proposals consisted of a spatially-explicit description of a local water-related problem they aimed to solve. Site location and dimensions, type of expected infrastructure, current land use and ownership, socio-economic characteristics, and existing conflicts were demanded to be included in each proposal. Economic aspects were not discussed because implementation costs were covered by the research project. Willingness to collaborate was stated as a requirement to be selected. The content of the proposals and the discussion during the workshop fed back the initial conceptualization of the existing water stage by providing further insights about preferences and perceptions and also supported the identification of a site for the second study phase.

A site considered in one of the proposals was selected based on its suitability, spatial replicability, and potential transition of the existing system through non-conventional measures. Proposals were considered feasible if an explicit expression of interest to participate was stated and the data provided showed consistency when comparing them during a site visit. Proposals were discarded if they were located in private properties where no interest from the owners or relevant problems related to the study were reported. Furthermore, the water-related issues described in the proposals could not be too specific, so that replicability and upscaling remained possible. Finally, a proposal had to represent an evolution of the existing system based on the Urban Water Transition Framework (Table 1). Although it was not explicitly stated, any proposal aiming to extend the existing conventional system was discarded.

\subsection{Second Phase: Simulation of a Potential Transitional Stage}

Once selected, its spatial and infrastructural aspects, hydrological characteristics, as well as social preferences and perceptions related to water issues, were mapped and monitored in the neighborhood. This information was used to conceptualize the urban water transition stage and to design an adapted SUDS prototype, approved later by local authorities. As a result of the planning and design activities, the potential evolutionary stage of the urban water system was formulated. Subsequently, administrative constraints were also identified during the formal procedures for construction. After implementation, it was monitored regarding its performance, maintenance, and social reaction. Figure 3 summarizes the activities executed during this phase. 


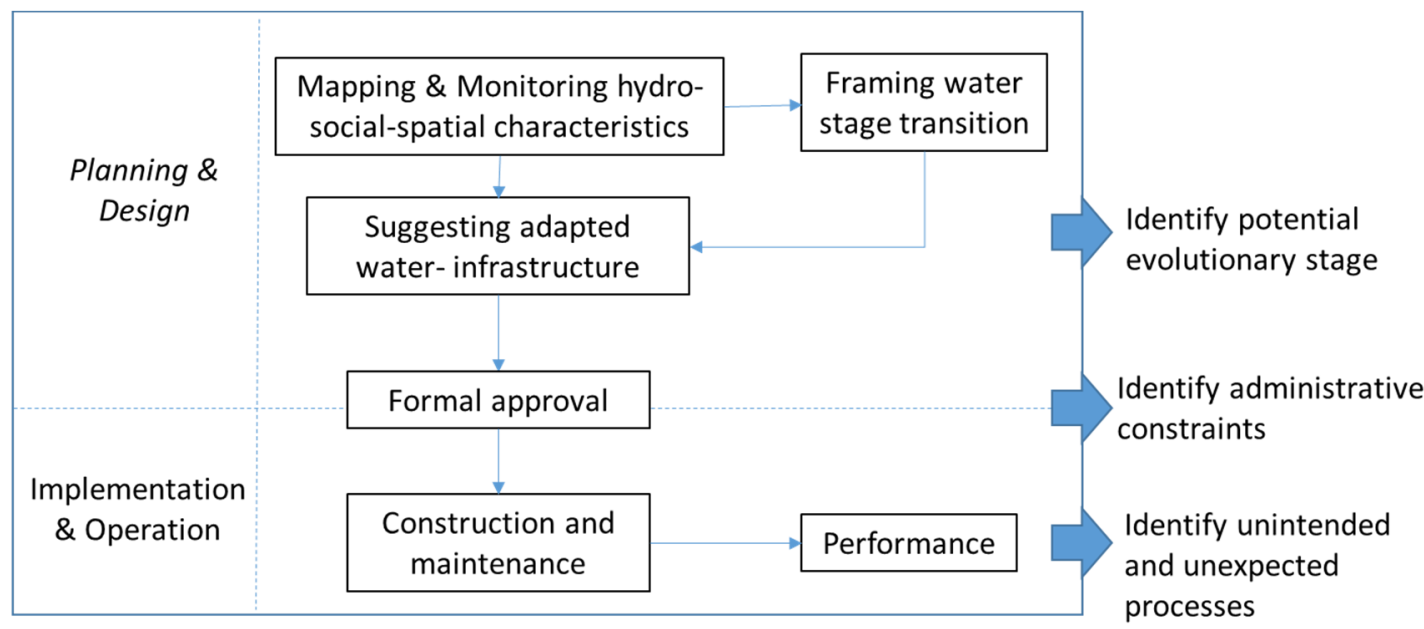

Figure 3. The procedure employed to identify potential dynamics occurred during and after implementation of a prototype to simulate a transitional stage in a specific neighborhood.

\subsubsection{Mapping Hydro-Social-Spatial Characteristics}

Spatial characteristics were defined by a Land Cover/Land Use (LULC) classification, and by onsite visits to measure specific dimensions. The percentages of LULC at the watershed and neighborhood-scale were determined by applying a high-resolution imagery classification methodology [39]. An open-access satellite image was obtained from Google Earth Pro 7.3.3 (C) corresponding to the year 2020. Impermeable areas (i.e., buildings, streets), vegetation (trees, shrubs, and open grass spaces), and bare land (i.e., vacant land) were selected as LULC classes. Although different LULC classes can exist in the same place (e.g., buildings underneath trees), the upper class was assumed to represent the visualized area. This assumption did not influence significantly the final results of this research since the hydrological response associated to the LULC is not the scope of the study. Topography and infrastructure were surveyed onsite, including stormwater infrastructure and street dimensions. The local municipality provided a digitalized georeferenced database of lots, which was employed to distinguish between private and public spaces.

Social preferences, perceptions, and attitudes were expressed by 25 residents. They were adults, living within the limits of the neighborhood, in a similar male-female proportion. Residents were contacted in public spaces or front yards. Moreover, two public events were co-organized with local authorities to inform residents about the scope of the study attempting to increase participation and interest in the project. People were also contacted during hydrological monitoring and onsite surveys. Residents were asked about their main concerns from a general perspective, as well as socialand water-related issues. After a short introduction explaining the research, interviews followed a non-structured conversation scheme.

To characterize the local hydrology, a tipping-bucket rainfall collector (Hobo ${ }^{\circledR}$ RG3, Onset, U.S.) with a resolution of $0.2 \mathrm{~mm}$ was installed in the study area. Rainfall was monitored for one year, including the wet season of the year 2019. Additionally, two meteorological stations running as part of a municipal flood alert system provided a 5-min step interval and $0.2 \mathrm{~mm}$ resolution rainfall data for the previous three years. They were located up- and downstream of the collector installed in the neighborhood, at a distance of $1 \mathrm{~km}$, and consisted of tipping-bucket rain-gauges. Furthermore, five residents who showed interest measured rain events using rain gauges. They were trained for the correct use of the instrument before installation in the open space of their backyards. The residents sent an image of the accumulated volume via the internet if a rainfall event occurred the day before. Those data were used to validate the automatic rain gauge. Stormwater runoff was monitored using an ultrasonic flow sensor (PCM PRO ${ }^{\circledR}$, Nivus, Germany) installed in the sewer near its outfall, recording water depth with 2-min time-step resolution. 


\subsubsection{Small-Scale Demonstration for Simulating a Consecutive Transitional Stage}

The prototype was designed at the micro-urban watershed scale based on the aspects described in Figure 3. Assuming a future linear evolution, the new infrastructure elements were adapted to the existing drainage system. It included a hydrological-hydraulic simulation of the rainfall-runoff performance in the stormwater sewer system using the rainfall-runoff data [40]. The simulation provided insights into the expected hydraulic performance of the prototype. Moreover, the spatial characteristics derived from the LULC classification, as well as the perspectives for management reported by the local authorities were considered during the design. The operational principle was presented to the local authorities who approved its construction. The local authorities called for tenders for the construction. The most economical bid presented by a local engineer with proven experience working with the municipality was selected.

\section{Results}

\subsection{Multi-Scalar Preferences and Attitudes}

An engineering-hydraulic perspective of infrastructure efficiency and environmental concerns were identified from the constellation of actors as key factors ruling their preferences. Issues related to urban drainage, stormwater runoff, and greywater were highlighted as aspects to be solved in urban areas of the watershed. However, those aspects differed slightly depending on the actors involved at each spatial scale. These points are summarized in Table 2.

The main concerns at the watershed level were related to the effects derived by rapid and uncontrolled urbanization. A lack of both conventional sanitary sewerage and wastewater treatment plants, as well as the periodical flooding in some areas, were perceived at the municipal and watershed level as the most critical aspects. Most of the buildings use single septic tanks to treat blackwater, except for new private residential complexes and industrial areas having their treatment plants. To a great extent, greywater is discharged into the street curbs or directly connected to the stormwater sewer collector to be disposed into the river. Despite being illegal, this practice is preferred by many residents to reduce the maintenance cost of septic tanks. A hydraulic-efficient network of reticulated sewers ensures a rapid conveyance of stormwater runoff in most of the urban areas. A wastewater sewer system and a central treatment plant are envisaged by the authorities to advance the water management, but at a slow step due to administrative and economic limitations.

Flooding is not a spatially homogeneous concern. Its negative effects were reported at the watershed and municipal scale in all the interviews, but only downstream municipalities proposed related solutions. Flooding is identified near old bridges or morphological bottlenecks of the river. To solve it, the enlargement of bridges and artificial river embankments are adopted as an engineered control measure. On the other hand, not all residents were aware of the flooding issue in the river, and some of them did not even know the existence of a river in the surroundings. In one neighborhood, four residents living about $300 \mathrm{~m}$ away, expressed that they have never visited a river in the area. The latter was probably due to the uphill location of their residences. Nonetheless, people whose flooding issues were solved in the previous years recognized the temporality of the measures by expressing negative expectations in the future and perception of increasing water level each year.

A legal complaint from a resident living next to the river, in the middle section, resulted in a constitutional court decision that mandates three municipalities and water-related institutions to assume responsibility for watershed management in an integrated manner. This mandate was stated by the municipal representatives as a means to protect the environment and public health, as well as a way to enhance cooperation among actors. Granting new permissions for direct runoff discharge was consequently banned, requiring technical control measures instead. 
Table 2. Aspects related to the water management identified as relevant by local actors at different scales.

\begin{tabular}{|c|c|c|c|}
\hline & Aspect & Expressed Concerns & Existing Solution \\
\hline \multirow{3}{*}{ Watershed } & $\begin{array}{l}\text { Lack of sanitary } \\
\text { sewer system }\end{array}$ & $\begin{array}{l}\text { River as a receptor of } \\
\text { greywater and } \\
\text { industrial effluents }\end{array}$ & $\begin{array}{c}\text { Planning centralized } \\
\text { wastewater treatment plants. } \\
\text { Control and regulation. }\end{array}$ \\
\hline & $\begin{array}{l}\text { Flooding in } \\
\text { specific points }\end{array}$ & $\begin{array}{l}\text { Increasing runoff as a } \\
\text { consequence of urbanization }\end{array}$ & $\begin{array}{l}\text { Regulating permits for } \\
\text { construction. Increasing flow } \\
\text { capacity by enlargement } \\
\text { of bridges. }\end{array}$ \\
\hline & Legal aspects & $\begin{array}{l}\text { Constitutional court mandates } \\
\text { institutional responsibility } \\
\text { (e.g., municipality) to solve } \\
\text { problems related to flooding, } \\
\text { water quality, } \\
\text { and river degradation }\end{array}$ & $\begin{array}{l}\text { Ban new permits for } \\
\text { wastewater and stormwater } \\
\text { discharge to the river without } \\
\text { previous treatment. }\end{array}$ \\
\hline \multirow{3}{*}{ Municipality } & $\begin{array}{c}\text { Relations } \\
\text { up-downstream }\end{array}$ & $\begin{array}{l}\text { Fragmented responsibilities } \\
\text { and blaming between } \\
\text { stakeholders about granting of } \\
\text { new construction permits }\end{array}$ & $\begin{array}{l}\text { Detention ponds to control } \\
\text { stormwater runoff. New } \\
\text { municipal regulatory urban } \\
\text { development plans. }\end{array}$ \\
\hline & Public green spaces & $\begin{array}{l}\text { Degradation of the } \\
\text { riparian zone }\end{array}$ & $\begin{array}{l}\text { Fencing. Clean-up activities, } \\
\text { reforestation, } \\
\text { and recycling campaigns. }\end{array}$ \\
\hline & Flooding ${ }^{1}$ & $\begin{array}{l}\text { Erosion river channel, } \\
\text { inundations of buildings }\end{array}$ & $\begin{array}{c}\text { Artificial river embankment, } \\
\text { dikes, relocation of houses. } \\
\text { Flood alert system. }\end{array}$ \\
\hline \multirow{3}{*}{ Neighborhood } & Riparian area & $\begin{array}{l}\text { Undesired odors, rodents. } \\
\text { Informal dumping of solid } \\
\text { waste. Memories about } \\
\text { the river }\end{array}$ & $\begin{array}{l}\text { Report the local authorities. } \\
\text { Interdiction to access/ }\end{array}$ \\
\hline & Security & $\begin{array}{l}\text { Vandalism and illegal } \\
\text { activities in open green spaces } \\
\text { and riparian areas }\end{array}$ & $\begin{array}{c}\text { Fencing of playgrounds, } \\
\text { limited opening hours, and } \\
\text { passage. } \\
\text { Situating religious figures. }\end{array}$ \\
\hline & Infrastructure & $\begin{array}{c}\text { Need for paved streets as a } \\
\text { status symbol of } \\
\text { urban development }\end{array}$ & $\begin{array}{l}\text { Reduction of vegetation } \\
\text { along streets. }\end{array}$ \\
\hline
\end{tabular}

${ }^{1}$ Reported only by two municipalities.

A permanent solution for the flooding issues is expected to be formalized through the on-going urban planning regulations of each municipality. One municipality expressed the intention of developing water management approaches by considering rainwater harvesting. That institution highlighted the amount of precipitation along the year in the region and the over-exploitation of local aquifers. The new regulations were also envisaged as a possible solution to reduce domestic water consumption by mitigating water supply interruptions reported periodically by residents.

Regarding public green spaces, limiting people's access to those areas is seen as a permanent and effective solution for environmental protection. Fencing along natural river corridors and playgrounds is a widespread practice across the watershed. It was reported as either a private measure along rivers or public demand in playgrounds to reduce vandalism, which in turn reduces maintenance costs of green spaces. Public support exists for this measure because residents are in charge, in some cases, of controlling accessing hours to playgrounds. However, hidden inaccessible spots, especially in the riparian zone, are perceived as conflictive areas. Therefore, security was the main concern identified at the neighborhood scale. 
In already built areas, the extended yet illegal domestic discharge of greywater into the streets is adapted to the local socio-political dynamics. From the residents' perspective, there is a general preference for paved streets and rapid conveyance drainage systems that periodically clean the streets after rain events. The implementation of sanitary sewers, though desired, might be beyond their affordability because new sewer connections would be necessary. The construction of additional rooms attached to the initial building configuration is an extended practice to expand the space of houses, which takes place normally over surfaces where domestic septic tanks were installed. Economic limitations to connect existing infrastructure to new sanitary sewers seem to be a major constraint to progress in the development of wastewater infrastructure, from the perspective of actors at all three scales.

Another issue perceived at the neighborhood scale is related to the existence of public vegetation. Public concern exists about the potential damage that roots may cause to paved streets and buildings, or the danger of tree branches near power lines. Clogging of catch basins due to falling of leaves and debris causes stagnant water in different points, thereby undesired aesthetics and odors. In any case, residents commonly prefer to hold local authorities accountable for unclogging the catch basins. In addition, the existence of high dense vegetation in undeveloped lots is seen as potential spots for vandalism. In general, residents stated that security is a priority rather than water issues unless the water supply shortage is solved.

\subsection{Proposals from Municipalities for Implementation}

A summary of the proposals received from the municipalities is presented in Figure 4. It includes the total area at each site, based on the potential location of a prototype and the neighborhoods connected directly to the area. Two proposals were submitted by each municipality within the following weeks after the workshop. All of them were located along the river. Their areas of influence present LULC distributions corresponding to ranges between $30-50 \%, 31-55 \%$, and $7-26 \%$ for impermeable, vegetated, and bare-land cover, respectively. A combination of residential, agricultural, and riparian protected areas defined the LULC at each site. The locations were exclusively considered in vegetated or vacant land, except in one case where the control of stormwater runoff was proposed along streets. Seven of the eight proposals focus on public spaces as potential sites arguing the suitability and feasibility

Proposals evidence the local understanding of water-related issues and the different technologies envisaged as solutions by the representatives approached during research. Regarding the type of technologies, channelization of the river was included as a measure for flood control in one case. This proposal was discarded because it does not fit in the linear continuum evolution assumption of the urban water system transition framework employed in this study. The proposals of three sites located in low areas highlighted the need for flood control measures. On the other hand, the sites located at higher elevations were expected to increase recreational areas and protection of the riparian zone. While there was not a preferred type of technology, suggestions included wetlands, detention ponds, or infiltration trenches. One proposal suggested green roofs in a private lot with exclusive agricultural land use. Since proposals were asked to address existing water-related issues, such proposal was discarded given the inexistence of both roofs and a specific plan for urban development. for implementation.

In general, proposals were based on combined measures to be potentially developed during interventions along riparian corridors or when vacant areas are subject to urbanization. It reflects the existing preference for undeveloped areas as potential sites for counteracting effects of urbanization related to urban water management. The location and land cover distribution of each proposal also suggest that retrofitting of already built urban areas is not accounted for experimentation. End-of-pipe solutions related to urban drainage for flood control shape the principal preference of local decision-makers in the study area. Potential elements located at the river shore constitute mitigation measures that reduce negative effects along the river, taking advantage of available space, but avoiding disturbing the existing urban development. 


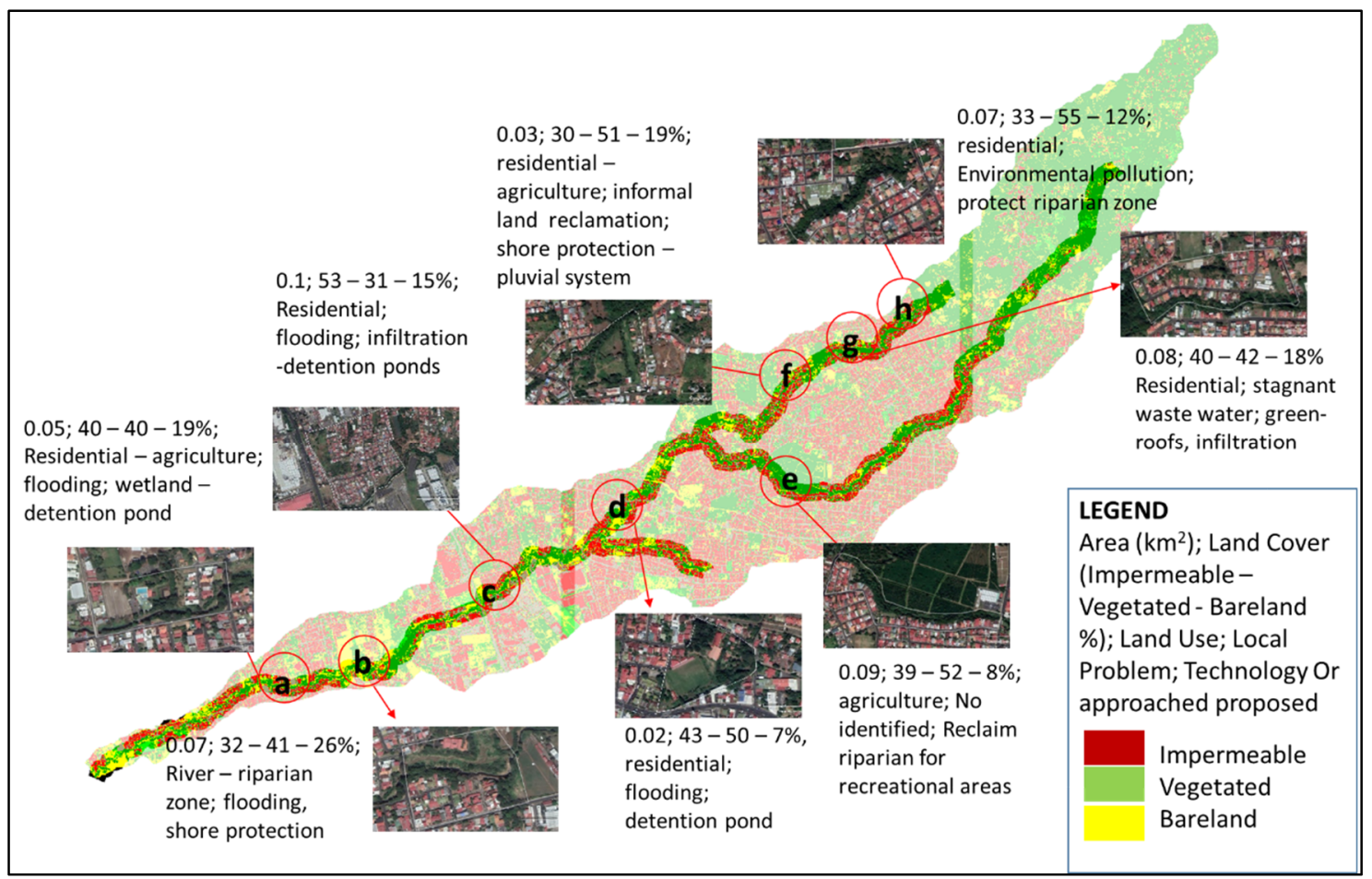

Figure 4. Summary and location of proposals presented by representatives of municipalities. Source of satellite images: Google Earth.

\subsection{Identification of the Transitionary Urban Water System Stage}

An efficient drainage system, the type of infrastructure preferred to control water-related problems, and the physical distance between society and water dynamics define the existing socio-hydrological context at the watershed level. Those aspects have ensured, at least temporally, protection of public health against water-borne diseases and have also reduced the impacts from flood events. Although an extended water supply distribution network exists, intermittent water shortages occur frequently. The wastewater effluents drained in the reticulated sewer networks ensures a rapid discharge of stormwater- and dry-weather runoff to the river. Surface dry-weather runoff (i.e., domestic greywater) is a particularity of the local urban water management, observed in most of the watershed. Concerns related to wastewater disposal in public spaces are presented as a need for more sanitation infrastructure.

The promotion and adoption of existing measures to protect population and ecosystems are mostly a consequence of a legal conflict between citizens and institutions, solved by a court decision (locally referred to as the "voto 4050"). Conventional infrastructure to address the conflict is the common choice among local decision-makers. For example, planning and constructing a centralized wastewater treatment system was addressed by different stakeholders as the most suitable option. Moreover, detention ponds are required in new buildings to reduce hydrological effects from impermeable areas. On the other hand, concerns expressed during interviews were related to the potential pollution of local aquifers if infiltration of domestic grey-and stormwater runoff occurred as potential onsite management practices. The latter is magnified by the location of some drinking water wells within residential areas. However, the existing risk for local aquifers resulting from inefficient or under-dimensioned septic tanks was omitted from the local actors.

Regarding the interaction between society and water, the lack of both social responsibility and a sense of community seems to be a barrier for the maintenance of the drainage network, especially when clogged catch basins are neglected by residents. Municipal employees must continuously clean the urban drainage system after intense rain events or a prolonged dry season. Both the drainage 
configuration and level of imperviousness in urban areas have created a local sense of protection against environmental effects, at the cost of pollution and degradation of the river as well as limiting public green spaces.

Those aspects suggest a combination of Stages I, II, and III to contextualize the study case to the Urban Water Transitions Framework. The results show that: (a) Stages II and III predominate in the watershed, ruling both public health and infrastructure protection against flooding; (b) water shortages and intermittent supply limit an integral evolution from Stage I; (c) progressing towards Stage IV is constrained by the preferences for social security and spatial connection between infrastructure and ecosystems, especially riparian areas; and (d) no characteristics related to Stages V and VI were observed. Moreover, improving stormwater quality management was not reported as a relevant issue, which is assumed to be a limitation to evolve to Stage IV, linked to the unclear or unknown use of ecological engineering technologies.

\subsection{Site Selection for an Experimental Prototype}

A $0.12 \mathrm{~km}^{2}$ residential neighborhood was selected for constructing the prototype. It is located in the middle section of the watershed and near the administrative boundary of three municipalities. Commercial, industrial, and agricultural activities exist in the surroundings. The land conversion from coffee plantations to buildings dates from before the year 2000. However, urbanization was accelerated after this year by the rapid expansion of the Great Metropolitan Area of San José, and the relocation of international companies to an industrial area nearby. Figure 5 shows an overview of the selected area and its evolution during the last two decades, as well as a classification of the existing land use and existing water-infrastructure. The LULC classification shows that impermeable areas including buildings and streets count for about $57 \%$, vegetated areas account for $18 \%$, and vacant land account for $21 \%$.
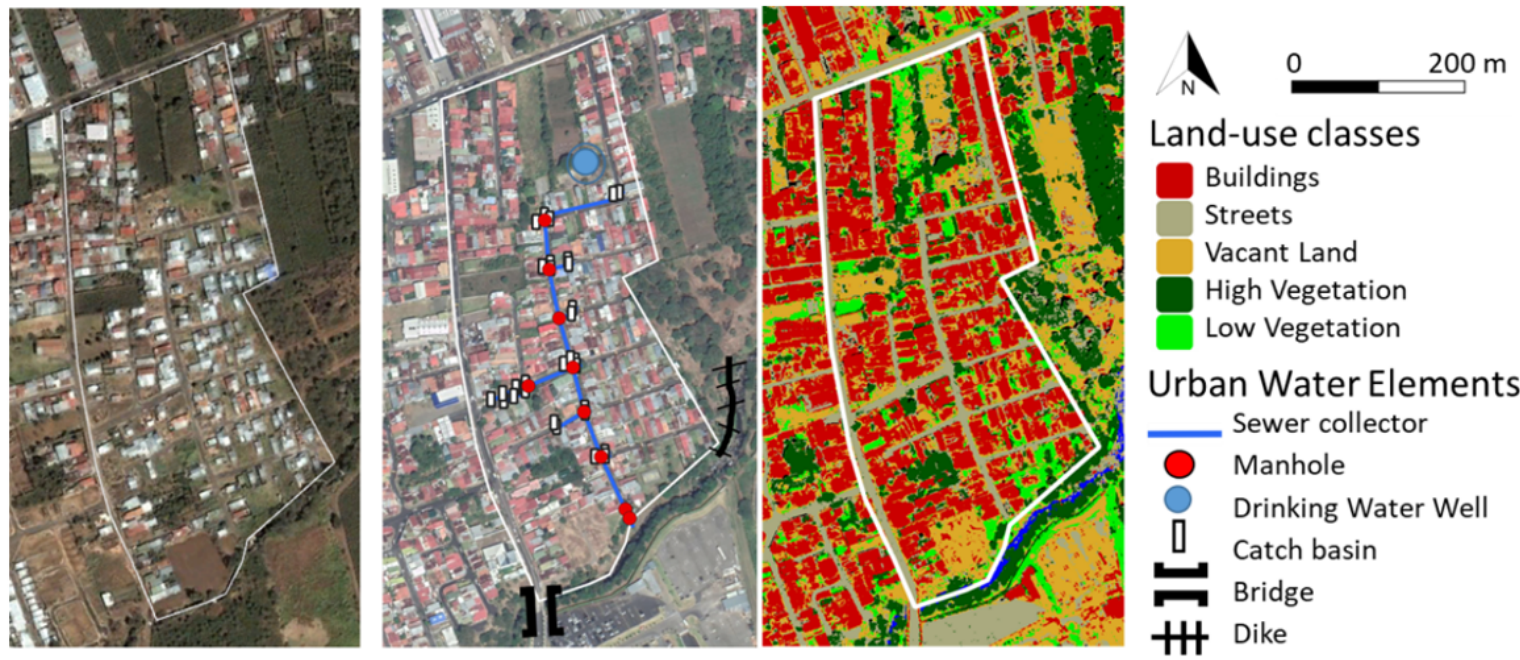

Figure 5. The area selected for implementation (white line) in the year 2003 (left), and in the year 2020 including the existing water infrastructure (middle), and the Land-Use Classification (right).

Regarding the built environment, all streets are paved. All the streets have strips of grass, plants, or shrubs planted between the $1 \mathrm{~m}$-width sidewalk and the two-lane driveway. An increase in traffic across the neighborhood was reported in the last few years due to its proximity to free-trade zones in the south, the area serves as a bypass during traffic jams. Most of the buildings are one- or two-floor single-family houses. As in most of the entire watershed, the wastewater load on septic tanks is reduced by draining greywater into the curbs, being conveyed into the river through a sewer collector.

Clogging of catch basins is periodically reported to the local authorities. Public discomfort exists about permanent stagnant water in some of those points. Uphill-living residents are perceived by 
their downhill neighbors as responsible for the problem because of a lack of social responsibility. To solve the issue, municipal employees maintain the system by unclogging the duct periodically. Despite being a tropical area where water-borne diseases may exist, no public health issues were explicitly communicated in the area. It could be due to the continuous renewal of the stagnant water by dry-weather runoff or after intense rain events.

Due to the topographic gradient of the area and the efficient $75 \mathrm{~cm}$-diameter sewer collector serving the neighborhood, no pluvial flooding issues exist along the streets. In the past, overflow of the river was solved by expanding the bridge carrying capacity downstream, and the construction of a dike upstream. The main concerns along the river are the accumulation of solid waste and wastewater, especially at the end of the streets, creating social nuisance against those areas. Moreover, erosion of the stream bank endangers the buildings located in the protection zone. The use of public spaces along the shore for private gardening or drug consumption and the existence of a separated fenced playground suggests a territorial tolerance and spatial equilibrium for the distribution of different social activities.

\subsection{Prototype Design, Implementation, and Performance}

The existing conditions at different spatial scales suggest that the evolution of the urban water system would have to consider the following aspects related to the linear continuum transition of the Urban Water Framework: (a) Flooding should not be solved exclusively by end-of-pipe engineering-driven approaches; (b) the inclusion of stormwater quality management aspects; (c) increasing access and multifunctionality of green open spaces, especially along natural ecosystems such as rivers; and (d) developing ecological engineering technologies such as bio-infiltration systems to protect receiving waterways.

Moreover, options for implementation were limited by normative regulations about street dimensions related to the exclusive use of streets for transportation. It impeded any proposal in those areas such as the transformation of driveways into green spaces. Another limitation was the locally perceived potential pollution of groundwater if infiltration of dry-weather or stormwater runoff occurred in residential areas or near wells supplying drinking water. The limited contact with the residents and lack of opportunities to approach them discarded any implementation at a domestic scale to represent the entire neighborhood. Consequently, the prototype was proposed as a gray-hybrid element for first flush bio-treatment and runoff detention. Figure 6 shows a scheme of the system, including structural modifications to the existing system.

The final section of the existing sewer was transformed into a temporal runoff storage tank. The diameter at the outfall was reduced from 75 to $7 \mathrm{~cm}$, thereby increasing the concentration time in the system to reduce the peak flow. To avoid clogging the orifice, a mesh with an open diameter of $5 \mathrm{~cm}$ was proposed in the adapted manhole, so solids were drained after intense rainfall events. When the storage capacity was surpassed, the runoff was discharged to the river using a bypass adapted in the manhole located before the original outfall, as shown in Figure 6. Maintenance of the system by the periodical cleaning of the manhole and the mesh in it was planned by municipal employees.

Regarding the bio-treatment, a $10 \mathrm{~cm}$ pipe conveyed by gravity both dry-weather runoff and stormwater first flush from the adapted sewer to an underground infiltration area. Greywater passes through a $3 \mathrm{~m}^{3}$ volume capacity sedimentation chamber connected to the existing collector before the volume provided for storage, as shown by the arrows in Figure 6. Then, the water passes to the $160 \mathrm{~m}^{2}$ infiltration area located in a public vacant land next to the riparian corridor. A $5 \mathrm{~m}$-length perforated pipe was placed across the $30 \mathrm{~cm}$-width infiltration layer of gravel-chipped rock fragments. The hydrological performance of the system was tested by a hydrological model developed using the software PCSWMM (CHI, Guelph, Canada) [40]. 

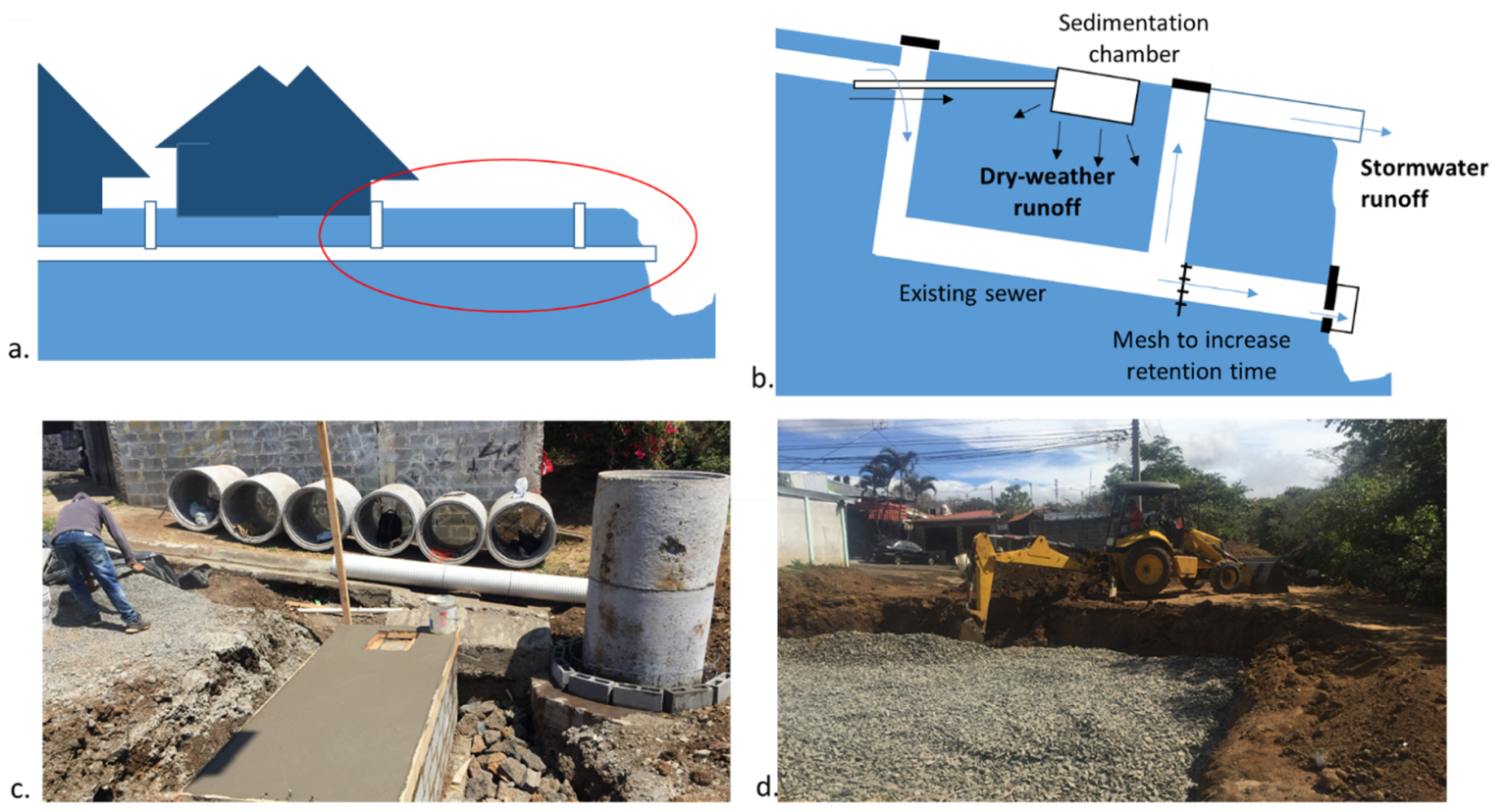

Figure 6. Scheme of the prototype implemented in the study site. (a) Drainage network previous intervention and (b) diagram of the adapted prototype including separation of dry-weather and stormwater runoff. (c) Sedimentation chamber and adapted manhole for overflow and (d) bio-retention area during construction.

Initial attitudes in the neighborhood were related to the implementation as an opportunity to improve the local aesthetics, as well as to reduce odors and vandalism. The simultaneous bio-infiltration treatment was perceived as an innovative adapted approach the capability of being considered in other areas, from local authorities. Reforestation with fruit trees was asked for by some neighbors to increase the social functionality of the area and to reduce the social conflict of illegal activities occurring there (i.e., drug consumption). Stabilization of the area against erosion was planned by planting Bambuseae as suggested by a local university working with this species.

Although social aspects were attempted to be included in the design, unexpected processes and events occurred which limited the operation of the system. A combination of mechanical, institutional, and social aspects influenced the continuous operation of the experiment. Despite the correct hydrological performance of the system, the emergent processes altered its operation and ultimately, the continuity of the operation of the system. Those aspects are summarized in the following as the clogging-unexpected effect, the disparities related to the involvement of residents, and the role of local decision-makers.

Since the conveyance of solids through the main sewer collector was known but not quantified, continuous cleaning of the mesh was conducted by local workers. The assumption that such an amount was irrelevant and the technical difficulty of placing correctly the mesh made the constructor decide to install it in an up-sewer manhole. It resulted in the overflow of the manhole after a rain event because of clogging by solids, including clothes, plastics, and branches. Although a simple solution might have been to relocate the mesh to the originally designed position, public discomfort about the project was already a limitation that impelled to cease permanently the operation of the prototype.

Resident interest and understanding of the project also impacted the experiment. It was assumed that most of the residents living in a $50 \mathrm{~m}$-ratio were aware of the project because of communication activities done previously, and the approach to the site construction because of curiosity. On the other hand, residents not willing to participate expressed that the project was irrelevant. It created spatially fragmented participation which limited direct communication between researchers and the community. Complaints from residents were reported to the authorities due to the noise and dust produced during construction, temporal shut down of the water service, and finally the temporal 
overflow of the manhole holding the mesh. It caused the representative of the local authority to demand the experiment be stopped.

A shift related to the collaboration approach occurred between researchers and decision-makers during the construction phase. Interaction with the municipality took place exclusively through one representative, who acted as a bridge with the local institution. This person acted as a representative of the mayor during the phases of design, approval, proposals, and interviews. His interest in urban water aspects was explicitly stated, and assumed by the researchers as a valuable aspect that reinforced collaboration. However, as it was unexpectedly informed, this person left the position days before construction started. The institutional role of the new person in charge was different. It shifted from a collaborative to an administrative and regulative perspective. In consequence, communication and coordination efforts were limited due to the new dynamics, and advanced stage of development of the project. As complaints were reported by neighbors, the role and responsibility of the different actors involved in the experiment were unclear.

In addition, uncertainty regarding the accuracy of field data forced us to adapt the hydraulic design of the prototype. Due to the inaccessibility or non-existence of the technical characteristics of the sewer system, its dimensions were manually measured. As a result, a manhole and a catch basin that were not initially mapped were discovered during the construction phase, as they were hidden underneath the soil covered by grass. In the past, the riparian corridor was used as a landfill to dump construction rubble and create flat areas for new residences. Although it did not affect the mechanical operation of the infrastructure, it was a critical issue that increased the complexity during construction and might have affected the constructor's choice for the location of the mesh.

Finally, only fruit trees were accepted by the community. The bamboo species planted in one corner was not well received because of the social perception around it. Residents removed it right after it was planted because they stated it might increase vandalism. As it is a high plant, it was later reported that hidden spots may appear, attracting illegal activities. This situation was discussed with the residents, after recognizing that vandalism is associated with the drug consumption that already exists in the area in public spaces. The alternative justification was associated with the possible endanger of the electric wires, although they were located away from the zone of influence of the plants.

\section{Discussion}

\subsection{Approach to Assess the Existing Urban Water Infrastructure}

The case of the Quebrada Seca shows disparities with the urban water infrastructure development reported in more developed countries. Employing the Urban Water Framework to the case study context presented limitations in categorizing the existing infrastructure state because there is not a specific stage that presents aspects of flood protection, deficient sanitation, and insufficient water supply, simultaneously. Therefore, a specific transition stage from the framework cannot be rigidly formulated because of (a) segregated urban areas within the watershed that present different technologies, practices, and water management characteristics, (b) the spatial fragmentation and heterogeneous access of people to specific water-related services and public spaces, and (c) divergences on the local understanding of the socio-hydrological drivers at different institutional and spatial scales. Those factors limit the application of simplistic linear frameworks. A more adapted approach to describe the urban socio-ecological dynamics related to urban drainage in the watershed could be discussed in future studies considering the social conflicts at different urban organization scales (i.e., neighborhoods or municipalities).

The main difference found in the relation of the Urban Water Framework was associated with the pertinence of priorities given by society (i.e., social security and vandalism), and the existing preference for the use of water bodies (i.e., protection of the river by structural measures), which influence the development of specific urban patterns. Linear evolution is not expected in the watershed Quebrada Seca, possibly leading to increasing social distance between different settlements and thereby the access 
to specific types of technology for water management. In consequence, locally adapted approaches are necessary to synthesize the understanding of developmental stages of the urban socio-ecological systems, especially in similar regions presenting social inequalities related to infrastructure and basic services.

Hydraulically efficient engineered infrastructure is a common characteristic of conventional stormwater systems [41]. Considering exclusively such systems could strengthen the existing conventional management model and create new path dependencies, thereby delaying transitional stages towards more holistically, multi-functional developments. For example, requiring the implementation of detention ponds in new constructions to reduce hydrological effects from large impermeable areas might become a limitation for progressing towards more ecologically sound stages. Since they are usually designed and operated to serve a single-hydrological function, they might limit the linear evolution of the urban water system. Nevertheless, a linear evolution considering the Urban Water Framework was shown to be not effective in the region.

One way to understand local disparities was by mapping attitudes, preferences, and social dynamics associated with water infrastructure. This allowed the identification of drivers that influence the development of infrastructure. A multidimensional priority for flood control over sanitation or ecological restoration was observed, including institutional, spatial, and societal perspectives. The local jurisdiction sentence ("voto 4050") aimed to address urgent measures to reduce the negative effects of rapid urbanization. One response mechanism was banning new permissions for construction and asking for reports of advances from the local authorities. However, it might indirectly become a pretext for long-lasting practices that only partially and temporally solve the flooding issue. For example, some actors acknowledge that an existing strategy to deal with the sentence is to overload the controlling institutions with large reports to discourage any further control. Economic investment in conventional measures such as expanding bridges, dikes, or dredging of the riverbed to increase the hydraulic capacity was found at the intersection between regional economic development and reactive protection measures against natural or man-made induced events. Such activities are commonly reported as measures realized to protect the river course and its inhabitants. Similar practices can be expected in the future if flooding is the predominant issue in the discussion of water management, and if local policies are not developed considering integral perspectives beyond engineering methods.

Another driver is related to the adaptation of residents to normalized urban environments. Since dry-weather runoff from households is widely accepted by different actor constellations, residents have adapted themselves to spatial dynamics and existing landscape development. It might be due to the willingness to avoid paying for expensive services for centralized water treatment systems, as construction is expected to be distributed among users in their billings. The normalized state is amplified by the responsibility that authorities have adopted to maintain periodically catch basins, and sewer systems in general. As a consequence, residents perceive that access to clean sewers is a right fulfilled exclusively by their municipal authorities. Although onsite control of greywater effluents should be a citizen obligation, relatively few aspects are discussed about it. Instead, a protectionist approach from the authorities is observed, for example, in the continuous investment in effective hydraulic structures that discharge as much and fast as possible. As a result, the degradation of the river is perceived by the actors' constellations as an unavoidable consequence of urbanization. Similar practices are commonly observed in stormwater management approaches to legitimize action [31].

The existing dynamics between access to open areas and a sense of social security against vandalism can be framed as a "fenced-gray preferential choice" for maintaining and developing water-related infrastructure under the existing socio-hydrological drivers. Public engagement to restrict access to playgrounds might reinforce the idea of social responsibility and participation, as well as increase the sense of community of specific groups, especially of citizens living in the same area for long periods. Fenced playgrounds and green areas are seen as desired public spaces from a portion of the population if they can ensure security aspects and specific types of activities. Riparian shores, on the contrary, 
are seen as conflictive zones. Their potential for ecosystem restoration and recreational spaces is still not envisaged due to the lack of public interest and the existing hydro-morphological degradation associated with the desired type of urbanization. Those areas are less popular due to the large number of drug consumers observed there, which has shaped a social contract of tolerance if spatial borders are respected. As result, physical and social barriers have created a relative dynamic equilibrium between citizens, river ecosystems, and public green spaces, caused mainly by the perception of social security.

Although the social protection of playgrounds may lead to an increase in public demand for more green spaces [19], the disparities of preferences between cage-like areas and river shores might be a limiting factor to expand the multifunctional use of the latter areas. Further research is necessary to understand the social dynamics between people, rivers, and green spaces. In this study, one limitation to understand such dynamics was the limited access to communication means with the population. Understanding such dynamics have the potential to develop strategic policies in a more integral socio-ecological context, considering the political discourse as well as economic development and sustainability.

\subsection{Site Identification for Simulation of Urban Water Transition}

The implementation of a prototype to simulate urban water infrastructure transition processes was based on the identification of an area at a micro watershed scale that shares similar characteristics with other areas at a larger scale. Different activities contributed to this goal, but especially the understanding of local authorities reflected in the proposals received from municipalities located within the watershed. Such proposals explicitly presented kinds of prototypes and spatial locations preferred by local planners and politicians for solving water-related issues. The potential use of riparian areas and river shores to reduce flood effects was observed in both the micro and watershed. The location of measures was mostly proposed at the outfalls of drainage sewers, which underlines the local preference for protection rather than more integral approaches. Since the availability of space for large complementary technologies is limited in built areas, riparian zones or vacant lots appeared as the most suitable areas.

Another aspect related to the site selection was associated with the historical LULC evolution, which follows a similar pattern of development in the region. The selection of the site was related to the residential character of the neighborhood, which land use distribution is similar at the watershed scale [35]. Coffee plantations shaped the landscape of the Great Metropolitan Area in the past [42], but land cover rapidly changed to a matrix of streets, buildings, and abandoned lands. Bridges and dikes were erected to connect and protect those new fragmented urban areas. Paradoxically, fences, walls, and barbed wires disconnected neighborhoods and other spaces from each other.

Moreover, specific aspects that do not necessarily exist in other areas of the watershed were found in the selected site, such as drinking water wells, dikes, and recently expanded bridges. Due to the social and institutional preference to protect those previously constructed urban features, the development of non-conventional measures that influence or adapt them is challenging. In our case, any experimentation located in the surroundings of those urban elements was rejected because local decision-makers had to fulfill regulative mandates and ordinances, mostly linked to policies for protection and conservation of natural resources and public infrastructure. This reflects a limitation of our approach to experiment with micro-scale prototyping, being necessary for previous changes in the regulatory legislation to provide opportunities for experimentation. Nevertheless, the particularity of the site considering those site constraints exhibits potential limitations at larger scales.

On the other hand, the procedure employed to define the site was constrained to the existing dynamics in the watershed. Although the involvement of different actors was expected, public participation was scarce due to the accessibility to directly contact and interact with residents. Upgrading neighborhoods is not a purely technical process, requiring integrated and comprehensive interventions that include local participation [43]. However, consultation and information instead of participation was an undesired but adapted circumstance of our research methodology. This barrier 
goes beyond the research capacity of temporal studies, making it necessary that a previous organization exist onsite to trigger the effective involvement of residents and execute place-based research.

Another limitation of the site selection is related to its representativeness for socio-hydrological dynamics at larger scales. Spatially fragmented interactions between up- and downstream stakeholders, as well as social disparities among neighborhoods and municipalities, reflect that the choice of the study area is limited to the experimental perspective. Since the urban area is not homogeneous, but a complex system product of the rapid expansion, different economic status resulted in segregated neighborhoods, which might need social protection and security from other neighborhoods. As result, spatial disparities exist between up- and downstream areas that influence the development and operation of adapted infrastructure. Furthermore, as flood control drives the interest of local actors, reducing the impermeability of urban surfaces uphill might be not as attractive as it is for users downstream. Consequently, the location of non-conventional technologies can be restricted to a "gradient" of interest, based on the preferred aspects across the watershed. This situation limits the representativeness of the site in the watershed to areas with direct access to the river, covered with basic services but social conflicts about the use of riparian shores.

In general, adopting a site at a micro-scale for experimentation has the potential to represent critical aspects at larger scales. Upscaling results must be limited to areas with similar characteristics related to accessibility, economic status, and existing infrastructure development, so their replicability presents less uncertainty. As described, the site selection was not only influenced by spatial dynamics but also by the perspective of stakeholders involved in the choice. While there are areas demanding protection of the river, other areas are asking for protection from the river. Understanding those dynamics requires the involvement of the different actors, which in turn requires participation and communication. Active participation of residents in the decision-making process might be one of the most challenging tasks for experimenting with novel water-related technologies in similar areas. This issue could be overcome by considering their preferences and priorities and adapting them to the experimental phases.

\subsection{Lessons Learned from the Experimental Transition Simulation}

The place-based research resulted in unexpected situations which were not envisaged initially. One of the main limitations was constrained to the existing legislation which impeded the specific placement of prototypes in the landscape. Thus, the protection of drinking water supply wells was regulated by ordinances that hampered any construction nearby to protect local aquifers, although informal infiltration from septic tanks exists. Similar policies might have also influenced the choice of local actors for riparian zones as areas with more acceptance to experiment since the perception of being conflictive spaces demands public investment in those areas.

Another limitation was the inherent dependence on local authorities for the execution of the project, which created a state of vulnerability easily destabilized during changes of bureaucratic personnel. The prototype proposed in this study revealed such situations that might be taken for granted or assumed as low-risk factors in similar studies, but in reality might determine their effective operation and upscale. Reducing the dependence on local authorities during research may require generic prototypes that can be easily translated to similar areas if unexpected unavoidable failures occur.

Due to the efficient stormwater sewer and the advanced level of land occupation, retrofitting urban areas appeared as an option to reduce the effects of urbanization and ecological improvement of local urban ecosystems. In degraded urban environments, retrofitting is envisaged in underground spaces as a set of effective measures [44]. Commonly labeled as gray-hybrid infrastructure, the idea is getting attention in areas with existing drainage networks in the region [45]. Our prototype simulated a micro-watershed unit of landscape water management, which mimics natural processes of infiltration and storage. It can be associated with the efforts to address hydrologic symptoms of the urban stream syndrome by considering natural flow paths [46], and on-source water management strategies. Additional considerations are, nevertheless, necessary in dendritic stormwater networks 
at larger scales [47] because they might result in unanticipated impacts with cascading effects due to synchronized amplified flow volumes [48]. Experimenting similar prototypes may contribute urban planners and stormwater practitioners to identify potential scenarios associated to the complexity of evolving drainage systems [49], as well as the need for practical readiness and openness from professionals for receptivity to change [50].

The implementation aimed to avoid high disturbances on the existing urban dynamics, including social aspects. However, it created unintended uncertainties among residents who were not directly involved or informed about the construction. The main issue was related to the unexpected presence of machines and external people experimenting with a task they were not aware of or did not perceive as necessary. Furthermore, the unexpected shift on the coordination responsibility from the local government hindered communication between researchers and residents. Consequently, the disconnected dynamics among actors resulted in a lack of space for information and discussion during critical phases. Moreover, the hydrological academic approach considered initially might have also influenced the results. Since urban drainage was identified as an issue in the watershed, a bias on the site selection for experimentation might have occurred linked to specific preferences done exclusively by representatives' authorities.

Our approach was based on a hierarchical preference of the decision-makers' perceptions of solutions. This might have led to defining strategies for water-related problems from a purely technical-hydrological perspective of river protection. Considering other local perspectives could have resulted in the selection of a different experimental site. Since decision-makers were mostly men, construction-related professionals working as local government technicians in environmental affairs, their preferences represent only a specific portion of the entire constellation of actors. More integrated approaches must be considered due to the socio-ecological dynamics existing in urban ecosystems [51], suggesting a broader transdisciplinary perspective. Our empirical experience suggests that local conditions must be linked in detail to both urban land and urban water management by including resident priorities, thereby increasing their participation.

The suitability of any experimental implementation should be firstly explored by considering existing social dynamics [52] and effects derived from disturbing spatial patterns. Preferences, from a subjective perspective, are the basis to accept and adopt bottom-up management strategies that aim to upscale experimental results. Creating an onsite basis for the effective identification of such preferences might require long work periods and pre-existing local organizations, which might be beyond political periods or academic research deadlines. In consequence, increasing the adaptive capacity of local planning frameworks is necessary to include unexpected changes or new knowledge systems, commonly omitted in the existing conventions [53,54].

A "catalyst" might be necessary to increase the sense of community, thereby organization and participation [55]. In the context of this study, such a catalyst is associated with the perception of security in open green spaces that rules residents' priorities. More place-based research is, therefore, required to create and adapt water-related concepts and frameworks in complex urban systems. Multifunctional spaces along riparian corridors to approach interconnected networks of nature-based solutions might support new management techniques for stormwater and dry-weather runoff treatment, as well as increase public access to green spaces and social connection with nature. In the context of the Quebrada Seca watershed, demand for social security against vandalism was observed as a key driver that shape social-ecological dynamics.

Given the willingness to cooperate from different municipalities, a strategic intervention that considers local dynamics between representatives and authorities is suggested to consider both regulatory limitations and expected social and spatial changes. Additional aspects that were not considered but might become relevant mechanisms for more integrated management approaches are cultural and religious aspects of the population. In two places, religious figures were located near the river, which had the effect of a reduction in vandalism due to the respect of locals to specific spots with 
a spiritual context. Nonetheless, those aspects must be carefully considered if they are attached in the design of non-conventional technology, including ethical issues, local interests, and preferences.

\section{Conclusions}

Individual and organizational receptivity for change towards a modification of an urban stormwater system was approached in this study. The approach considered the extensive mapping of perceptions and dynamics at different spatial scales, as well as spatial and hydrological factors that define the materialization of implementation strategies. The methodology presented voids that are difficult to fill only by disciplinary perspectives, showing the potential effectiveness of transdisciplinary approaches related to those systems.

Participation and involvement of residents were found as one of the main limitations to progress the evolution of urban drainage systems in urban areas lacking previous social organization. Furthermore, exclusive dependence on local authorities to progress the different phases of the research increases the rigidity of implementing experimental prototypes, thereby leading to the vulnerability of the project to fail when unexpected events occur. A more interconnected network of actors sharing similar perspectives is necessary to identify the potential of locally adapted experiments. Finding ways to build such networks remains a challenge in the study site due to the complexity of multi-dimensional dynamics between hydrological and administrative boundaries. Efforts in future researches are suggested to focus on that issue, especially on the type of stormwater infrastructure expected downand upstream.

Employing a conceptual framework of urban water transition is a potential tool to track and identify key aspects of stormwater management at different scales, as well as to justify action. We argue that the excessive amount of hydrological models promoting ecological services might support policymakers but might also lead to take for granted unknown social aspects. Action-reflection-action could be a philosophical approach for the experimentation of novel technologies within the urban socio-ecological system. More place-based experiences are necessary.

In this study, we identified a preference from local decision-makers to use remainder riparian zones as potential areas for end-of-pipe solutions. Reclaiming those lands for urban development may sound to technocrats as a logical choice since they can be commonly considered as undesired public spaces. However, it could lead to emergent unintended processes such as green gentrification or increasing social disconnection and contact with nature. Changing those perceptions might require long-lasting but necessary collaboration between different political, social, and cultural contexts.

Experimenting with novel nature-based technologies in areas where conventional systems have already developed temporal solutions may lead to unintended effects. The disturbance of the temporal stable systems was not well received by residents. As urban ecosystems are complex socio-ecological systems, effective stormwater management strategies should not only consider the importance of residents' participation but a common language to translate their interests in engineering designs. The challenge of combining aspects related to a lack of basic services and promotion of multifunctional nature-based solutions, including stormwater management, is to find effective ways of implementation, considering economic, technological, and professional limitations. Social co-responsibility is necessary and their participation depends on the satisfaction of priorities and social needs, as well as on the level of social organization.

Author Contributions: Conceptualization, F.C., M.P. and J.H.; validation, methodology, writing-original draft preparation, visualization, F.C.; formal analysis and investigation, F.C. and M.P.; writing-review and edition, F.C., M.P. and J.H.; supervision, project administration and funding acquisition J.H. All authors have read and agreed to the published version of the manuscript.

Funding: This research was funded by the German Federal Ministry of Education and Research (BMBF), grant number 01UU1704. 
Acknowledgments: The authors would like to acknowledge the Municipalities of Barva, San Rafael, Heredia, Flores, Belen, as well as CIEDES-UCR in Costa Rica for supporting field research. We also acknowledge support from the German Research Foundation (DFG) and the Open Access Publishing Fund of the Technical University of Darmstadt.

Conflicts of Interest: The authors declare no conflict of interest.

\section{References}

1. Shafique, M.; Kim, R. Green stormwater infrastructure with low impact development concept: A review of current research. Desalin. Water Treat. 2017, 83, 16-29. [CrossRef]

2. Dietz, M.E. Low Impact Development Practices: A Review of Current Research and Recommendations for Future Directions. Water Air. Soil Pollut. 2007, 186, 351-363. [CrossRef]

3. Dhakal, K.P.; Chevalier, L.R. Urban Stormwater Governance: The Need for a Paradigm Shift. Environ. Manag. 2016, 57, 1112-1124. [CrossRef] [PubMed]

4. Goonetilleke, A.; Thomas, E.; Ginn, S.; Gilbert, D. Understanding the role of land use in urban stormwater quality management. J. Environ. Manag. 2005, 74, 31-42. [CrossRef]

5. Walsh, C.J.; Booth, D.B.; Burns, M.J.; Fletcher, T.D.; Hale, R.L.; Hoang, L.N.; Livingston, G.; Rippy, M.A.; Roy, A.H.; Scoggins, M.; et al. Principles for urban stormwater management to protect stream ecosystems. Freshw. Sci. 2016, 35, 398-411. [CrossRef]

6. Karvonen, A. Politics of Urban Runoff: Nature, Technology, and the Sustainable City; MIT Press: Cambridge, MA, USA, 2011; ISBN 9780262516341.

7. Porse, E. Old Solutions and New Problems: On the Evolution of Urban Water Infrastructure and Environments. Ph.D. Thesis, University of California, San Diego, CA, USA, 2014.

8. Brown, R.; Keath, N.; Wong, T. Transitioning to Water Sensitive Cities: Historical, Current and Future Transition States. In Proceedings of the 11th International Conference on Urban Drainag, Scotland, UK, 31 August-5 September 2008; pp. 1-10.

9. Burian, S.J.; Edwards, F.G. Historical Perspectives of Urban Drainage. In Proceedings of the Ninth International Conference on Urban Drainage (9ICUD), Portland, OR, USA, 8-13 September 2002. [CrossRef]

10. Liu, L.; Jensen, M.B. Green infrastructure for sustainable urban water management: Practices of five forerunner cities. Cities 2018, 74, 126-133. [CrossRef]

11. Nesshöver, C.; Assmuth, T.; Irvine, K.N.; Rusch, G.M.; Waylen, K.A.; Delbaere, B.; Haase, D.; Jones-Walters, L.; Keune, H.; Kovacs, E.; et al. The science, policy and practice of nature-based solutions: An interdisciplinary perspective. Sci. Total Environ. 2017, 579, 1215-1227. [CrossRef]

12. Kabisch, N.; Korn, H.; Stadler, J.; Bonn, A. Nature-Based Solutions to Climate Change Adaptation in Urban Areas-Linkages Between Science, Policy and Practice. In Theory and Practice of Urban Sustainability Transitions; Springer: New York, NY, USA, 2017; pp. 1-11. ISBN 9783319560915.

13. Sharma, A.; Gardner, T.; Begbie, D. Approaches to Water Sensitive Urban Design: Potential, Design, Ecological Health, Urban Greening, Economics, Policies, and Community Perceptions; Elsevier Science: Amsterdam, The Netherlands, 2018; ISBN 9780128128435.

14. Barbosa, A.E.; Fernandes, J.N.; David, L.M. Key issues for sustainable urban stormwater management. Water Res. 2012, 46, 6787-6798. [CrossRef]

15. Fletcher, T.D.; Shuster, W.; Hunt, W.F.; Ashley, R.; Butler, D.; Arthur, S.; Trowsdale, S.; Barraud, S.; Semadeni-Davies, A.; Bertrand-Krajewski, J.L.; et al. SUDS, LID, BMPs, WSUD and more-The evolution and application of terminology surrounding urban drainage. Urban Water J. 2015, 12, 525-542. [CrossRef]

16. Shuster, W.D.; Garmestani, A.S. Adaptive exchange of capitals in urban water resources management: An approach to sustainability? Clean Technol. Environ. Policy 2015, 17, 1393-1400. [CrossRef]

17. Madureira, H.; Andresen, T. Planning for multifunctional urban green infrastructures: Promises and challenges. Urban Des. Int. 2014, 19, 38-49. [CrossRef]

18. Miguez, M.G.; Veról, A.P.; Carneiro, P.R.F. Sustainable Drainage Systems: An Integrated Approach, Combining Hydraulic Engineering Design, Urban Land Control and River Revitalisation Aspects. In Drainage Systems; Salik, M., Ed.; IntechOpen: London, UK, 2012. 
19. Andersson, E.; Barthel, S.; Borgstrom, S.; Colding, J.; Elmqvist, T.; Folke, C.; Gren, Å. Reconnecting Cities to the Biosphere: Stewardship of Green Infrastructure and Urban Ecosystem Services. Ambio 2014, 43, 445-453. [CrossRef] [PubMed]

20. Scott, M.; Lennon, M.; Collier, M.; Folez, K. Integrating Ecosystem Approaches, Green Infrastructure and Spatial Planning; EPA: Washington, DC, USA, 2016.

21. Roy, A.H.; Wenger, Æ.S.J.; Fletcher, Æ.T.D.; Walsh, Æ.C.J.; Ladson, A.R.; Shuster, Æ.W.D.; Thurston, Æ.H.W.; Brown, R.R. Impediments and Solutions to Sustainable, Watershed-Scale Urban Stormwater Management: Lessons from Australia and the United States. Environ. Manag. 2008, 42, 344-359. [CrossRef] [PubMed]

22. Rijke, J.; Farrelly, M.; Brown, R.; Zevenbergen, C. Configuring transformative governance to enhance resilient urban water systems. Environ. Sci. Policy 2013, 25, 62-72. [CrossRef]

23. Dhakal, K.P.; Chevalier, L.R. Managing urban stormwater for urban sustainability: Barriers and policy solutions for green infrastructure application. J. Environ. Manag. 2017, 203, 171-181. [CrossRef]

24. Spangenberg, J.H. Sustainability science: A review, an analysis and some. Environ. Conserv. 2011, 38, 275-287. [CrossRef]

25. Swanwick, C. Society's attitudes to and preferences for land and landscape. Land Use Policy 2009, 26, S62-S75. [CrossRef]

26. Lee, Y.; Kim, K. Attitudes of Citizens towards Urban Parks and Green Spaces for Urban Sustainability: The Case of Gyeongsan City, Republic of Korea. Sustainability 2015, 7, 8240-8254. [CrossRef]

27. Wang, Y.; Dewancker, B.J.; Qi, Q. Citizens' preferences and attitudes towards urban waterfront spaces: A case study of Qiantang riverside development. Environ. Sci. Pollut. Res. 2020, 27, 45787-45801. [CrossRef]

28. Derkzen, M.L.; van Teeffelen, A.J.A.; Verburg, P.H. Green infrastructure for urban climate adaptation: How do residents' views on climate impacts and green infrastructure shape adaptation preferences? Landsc. Urban Plan. 2017, 157, 106-130. [CrossRef]

29. Baptiste, A.K.; Foley, C.; Smardon, R. Understanding urban neighborhood differences in willingness to implement green infrastructure measures: A case study of Syracuse, NY. Landsc. Urban Plan. 2015, 136, 1-12. [CrossRef]

30. Olsson, P.; Folke, C. Local Ecological Knowledge and Institutional Dynamics for Ecosystem Management: A Study of Lake Racken Watershed, Sweden. Ecosystems 2001, 4, 85-104. [CrossRef]

31. Flynn, C.D.; Davidson, C.I. Adapting the social-ecological system framework for urban stormwater management: The case of green infrastructure adoption. Ecol. Soc. 2016, 21, art19. [CrossRef]

32. Hall, A.; Richards, L. Incorporating Green Infrastructure Practices at the Municipal, Neighborhood, and Site Scales. 2009. Available online: https://nepis.epa.gov/Exe/ZyNET.exe/P1005PKX.TXT?ZyActionD= ZyDocument\&Client=EPA\&Index=2006+Thru+2010\&Docs=\&Query=\&Time=\&EndTime=\&SearchMethod $=$ $1 \&$ TocRestrict $=$ n\&Toc $=\&$ TocEntry $=\& Q$ Field $=\& Q$ FieldYear $=\& Q$ FieldMonth $=\& Q$ FieldDay $=\& I n t Q F i e l d O p=$ 0\&ExtQFieldOp=0\&XmlQuery=\&File=D\%3A \%5Czyfiles $\% 5$ CIndex $\% 20$ Data $\% 5 C 06$ thru $10 \% 5$ CTxt $\%$ 5C00000013\%5CP1005PKX.txt\&User=ANONYMOUS\&Password=anonymous\&SortMethod=h\%7C\&MaximumDocuments=1\&FuzzyDegree=0\&ImageQuality=r75g8/r75g8/x150y150g16/i425\&Display=hpfr\& DefSeekPage $=x \&$ SearchBack=ZyActionL\&Back=ZyActionS\&BackDesc $=$ Results $\%$ 20page\&MaximumPages $=$ $1 \& Z y$ Entry $=1 \&$ SeekPage $=x \& Z y P U R L$ (accessed on 25 October 2020).

33. Oreamuno, R.; Villalobos, R. Estudios Hidrológicos e Hidráulicos en la Cuenca Quebrada Seca-Río Burío. 2015. Available online: http://ciedes.ucr.ac.cr/docs/informe-final-quebrada.pdf (accessed on 20 September 2020).

34. Vallette, C. L'Environnement s'Invite en Ville. L'action Collective Face aux Risques Environnementaux dans la Grande Aire Métropolitaine de San José (Costa Rica). Ph.D. Thesis, Université de Caen Basse-Normandie, Caen, France, 2013.

35. Masís-Campos, R.; Avendaño-Flores, I.; Rezes-Chaves, J. Cartogtraphy of the Socioeconomic and housing profile in the micro-basin of the Río Burío Quebrada Seca (Costa Rica). InterSedes 2020, XXI, 175-209. [CrossRef]

36. Carrillo Lopez, D.; Carvajal Aguilar, J.M.; Coto Campos, V.; Salgado Silva, J.; Herrera Nuñez, D.; Rojas Cantillano, C. Variacion del Oxígeno Disuelto en el Río Burío-Quebrada Seca, Hereida, Costa Rica, en el Periodo 2005-2010. 2010. Available online: https://repositorio.una.ac.cr/bitstream/handle/11056/7468/ variacion\%20del\%20oxigeno.pdf?sequence=1\&isAllowed=y (accessed on 20 September 2020).

37. Chaves Herrera, M.A.; Rojas González, A.M.; Rojas, J.; Aguilar Pereira, J.F. Hydrologic Modeling Analysis from Land Use Scenario Changes in Quebrada Seca and Bermudez Watershed. In Proceedings of the World Conference on Computers in Agriculture and Natural Resources, San Jose, Costa Rica, 27-30 July 2014. 
38. Masis-Campos, R.; Vargas-Picado, H. Incremento de áreas impermeables por cambios de usos de la tierra en la microcuenca del río Burío. Rev. Reflex. 2014, 93, 33-46. [CrossRef]

39. Chapa, F.; Hariharan, S.; Hack, J. A new approach to high-resolution urban land use classification using open access software and true color satellite images. Sustainability 2019, 11, 5266. [CrossRef]

40. Towsif, K.S.; Chapa, F.; Hack, J. Highly Resolved Rainfall-Runoff Simulation of Retrofitted Green Stormwater Infrastructure at the Micro-Watershed Scale. Land 2020, 9, 339. [CrossRef]

41. Burian, S.J.; Findlay, E.G. Historical Perspectives of Urban Drainage. Glob. Solut. Urban. Drain. 2020, 1-16. [CrossRef]

42. Rodriguez Vega, E. Biografía de Costa Rica, 4th ed.; Editorial Costa Rica: San José, Costa Rica, 2010.

43. Imparatio, I.; Ruster, J. Slum Upgrading and Participation: Lessons from Latin America. Directions in Development; World Bank: Washington, DC, USA, 2003.

44. Admiraal, H.; Cornaro, A. Future cities, resilient cities-The role of underground space in achieving urban resilience. Undergr. Space 2020, 5, 223-228. [CrossRef]

45. Romero-Duque, L.P.; Trilleras, J.M.; Castellarini, F.; Quijas, S. Ecosystem services in urban ecological infrastructure of Latin America and the Caribbean: How do they contribute to urban planning? Sci. Total Environ. 2020, 728, 138780. [CrossRef]

46. Askari, A.; Rippy, M.; Fletcher, T.; Feldman, D.; Peng, J.; Bowler, P.; Mehring, A.; Winfrey, B.; Vrugt, J.; AghaKouchak, A.; et al. From Rain Tanks to Catchments: Use of Low-Impact Development To Address Hydrologic Symptoms of the Urban Stream Syndrome. Environ. Sci. Technol. 2015, 49, 11264-11280.

47. Mejia, A.; Jovanovic, T.; Hale, R.L.; Gironas, J.A. Dendritic Connectivity, Heterogeneity, and Scaling in Urban Stormwater Networks: Implications for Socio-Hydrology. In Proceedings of the AGU Fall Meeting Abstracts, New Orleans, LA, USA, 11-15 December 2017; AGU: Washington, DC, USA, 2017; p. H43R-03.

48. Jovanovic, T.; Gironas, J.A.; Hale, R.L.; Mejia, A. Spatial connectivity, scaling, and temporal trajectories as emergent urban stormwater impacts. In Proceedings of the AGU Fall Meeting Abstracts, San Franscisco, CA, USA, 12-16 December 2016; AGU: Washington, DC, USA, 2016; p. H13C-1384.

49. Jovanovic, T.; Hale, R.L.; Gironás, J.; Mejia, A. Hydrological Functioning of an Evolving Urban Stormwater Network. Water Resour. Res. 2019, 55, 6517-6533. [CrossRef]

50. Cettner, A.; Ashley, R.; Hedström, A.; Viklander, M. Assessing receptivity for change in urban stormwater management and contexts for action. J. Environ. Manag. 2014, 146, 29-41. [CrossRef] [PubMed]

51. Frank, B.; Delano, D.; Caniglia, B. Urban Systems: A Socio-Ecological System Perspective. Sociol. Int. J. 2017, 1, 1-8. [CrossRef]

52. Schifman, L.A.; Herrmann, D.L.; Shuster, W.D.; Ossola, A.; Garmestani, A.; Hopton, M.E. Situating Green Infrastructure in Context: A Framework for Adaptive Socio-Hydrology in Cities. Water Resour. Res. 2017, 53, 10139-10154. [CrossRef] [PubMed]

53. McFarland, A.R.; Larsen, L.; Yeshitela, K.; Engida, A.N.; Love, N.G. Guide for using green infrastructure in urban environments for stormwater management. Environ. Sci. Water Res. Technol. 2019, 5, 643-659. [CrossRef]

54. Taguchi, V.J.; Weiss, P.T.; Gulliver, J.S.; Klein, M.R.; Hozalski, R.M.; Baker, L.A.; Finlay, J.C.; Keeler, B.L.; Nieber, J.L. It Is Not Easy Being Green: Recognizing Unintended Consequences of Green Stormwater Infrastructure. Water 2020, 12, 522. [CrossRef]

55. Chavis, D.M.; Wandersman, A. Sense of Community in the Urban Environment: A Catalyst for Participation and Community Development. In A Quarter Century of Community Psychology: Readings from the American Journal of Community Psychology; Revenson, T.A., D'Augelli, A.R., French, S.E., Hughes, D.L., Livert, D., Seidman, E., Shinn, M., Yoshikawa, H., Eds.; Springer: Boston, MA, USA, 2002; pp. 265-292. ISBN 978-1-4419-8646-7.

Publisher's Note: MDPI stays neutral with regard to jurisdictional claims in published maps and institutional affiliations.

(C) 2020 by the authors. Licensee MDPI, Basel, Switzerland. This article is an open access article distributed under the terms and conditions of the Creative Commons Attribution (CC BY) license (http://creativecommons.org/licenses/by/4.0/). 